\title{
Germination of Echium plantagineum L. seeds submitted to dormancy overcoming and variations in temperature, light and depth of sowing ${ }^{1}$
}

\author{
Rodrigo Roso ${ }^{2 *}$, Ubirajara Russi Nunes ${ }^{2}$, Juçara Terezinha Paranhos ${ }^{3}$, \\ Caren Alessandra Müller², Tiéle Stuker Fernandes², Eduardo José Ludwig ${ }^{2}$
}

\begin{abstract}
The objective of this study was to evaluate methods of overcoming dormancy, light regimens, temperature and depth of sowing variations in the physiological quality of Echium plantagineum seeds. The diaspores (agglutinated fruits from the seeds) were submitted to treatments using accelerated aging, potassium nitrate and gibberellic acid to overcome dormancy. A 7 x 2 factorial design was used to evaluate the temperatures $\left(5,10,15,20,25,30\right.$ and $35^{\circ} \mathrm{C}$ ) and light regimens (presence or absence of light). A $6 \times 2$ factorial design was used for sowing depth $(0,1,2,3,4$ and $5 \mathrm{~cm}$ ) and soil coverage (presence or absence of straw). In all experiments, a completely randomized design with four replicates of 50 diaspores was used. The main evaluations were germination, first germination count, germination speed index and emergence. The seeds showed dormancy, which was overcome by the immersion of the diaspores in potassium nitrate and gibberellic acid. The ideal temperature for germination was $20{ }^{\circ} \mathrm{C}$, showing greater germination in the presence of light, considered as preferentially positively photoblastic. The highest germination percentage occurred when the diaspores were positioned on the soil surface in the presence of straw.
\end{abstract}

Index terms: gibberellic acid, purple flower, photoblastism, potassium nitrate, straw.

\section{Germinação de sementes de Echium plantagineum L. submetidas à superação da dormência e variações na temperatura, luz e profundidade de semeadura}

\begin{abstract}
RESUMO - Objetivou-se avaliar métodos de superação da dormência, regimes de luz, variações da temperatura e profundidade de semeadura na qualidade fisiológica de sementes de Echium plantagineum. Para isso, os diásporos (fruto concrescido das sementes) foram submetidos a tratamentos utilizando envelhecimento acelerado, nitrato de potássio e ácido giberélico para a superação da dormência. Utilizou-se um fatorial 7 x 2 para avaliar temperaturas $\left(5,10,15,20,25,30\right.$ e $\left.35^{\circ} \mathrm{C}\right)$ e regimes de luz (presença ou ausência). Já para profundidade de semeadura $(0,1,2,3,4$ e $5 \mathrm{~cm}$ ) e cobertura de solo (presença ou ausência de palha) utilizou-se um fatorial $6 \times 2$. Em todos os experimentos foi adotado o delineamento inteiramente casualizado com quatro repetições de 50 diásporos. As principais avaliações realizadas foram germinação, primeira contagem de germinação, índice de velocidade de germinação e emergência. As sementes apresentam dormência, sendo superada pela imersão dos diásporos em nitrato de potássio e ácido giberélico. A temperatura ideal para a germinação foi $20{ }^{\circ} \mathrm{C}$, apresentando maior germinação na presença de luz, sendo consideradas fotoblásticas positiva preferencial. A maior porcentagem de germinação ocorreu quando os diásporos foram posicionados na superfície do solo, na presença de palha.
\end{abstract}

Termos para indexação: ácido giberélico, flor roxa, fotoblastismo, nitrato de potássio, palha.

\section{Introduction}

Echium plantagineum L., popularly known as purple flower, is an annual herbaceous species, which belongs to the Boraginaceae family, native from Europe and Northern

\footnotetext{
${ }^{1}$ Submitted on 01/05/2017. Accepted for publication on 05/19/2017.

${ }^{2}$ Departamento de Fitotecnia, Universidade Federal de Santa Maria, 97105900 - Santa Maria, RS, Brasil.
}

Africa, indicated as ornamental, melliferous and medicinal (Berti et al., 2007; Comunian et al., 2016). However, it is considered as an invasive plant in Australia, South Africa, Canada and South America (Sharma and Esler, 2008; Weston et al., 2012). As a survival and adaptation strategy, it shows
${ }^{3}$ Departamento de Biologia, Universidade Federal de Santa Maria, 97105900 - Santa Maria, RS, Brasil.

"Corresponding author <rodrigo.roso@hotmail.com> 
a mean production of 6,000 seeds per $\mathrm{m}^{2}$ and the occurrence of dormancy, which may be overcome on the soil, over time, or concomitantly with oscillations in the temperature, humidity, light and oxygen and carbon dioxide conditions (Piggin, 1976). This species presents quick growth and adaptation to temperature and photoperiod variations, high capacity to compete with agricultural crops and large leaf area production, and it is characterized as a weed (Forcella et al., 1986). In Brazil, it is widely distributed across the South region, causing damages due to the competition in agricultural crops and cultivated pastures, and it is difficult to control, since its germination is distributed throughout the year (Piggin, 1976). New infestations may occur after it has been controlled through mechanical or chemical methods.

According to Souza and Lorenzi (2012), E. plantagineum has a scorpioid inflorescence, with flowers with superior, bicarpelar, gamocarpelar and tetralocular ovaries (formation of a secondary wall on the ovary), with one egg by locule and ginobasic gynoecium, which separate during the maturation of the fruits, remaining united by the style base. The fruits are dry, indehiscent and with one seed, and the seeds remain attached to the fruits. The seeds are the dissemination and propagation unit (Moreira and Bragança, 2010). This species is naturally spread by the germination of the seeds; therefore, it is relevant to study its germination process. This process may be regulated by several factors, such as temperature, photoperiod, salinity, soil $\mathrm{pH}$ and seed deposition depth on the soil (Vivian et al., 2008; Duddu and Shirtliffe, 2014; Mahmood et al., 2016).

The seeds of species that are considered invasive species on crops may also be dormant. Dormancy is a phenomenon in which seeds do not germinate, even though they are viable and have all favorable environmental conditions to begin the germination process (Azania et al., 2009; Gama et al., 2011). This phenomenon assures the survival of the species under adverse conditions after the maturation and dispersion of the seeds, allowing the germination to occur with time (Pazuch et al., 2015). Several causes may be related to dormancy, such as tegument impermeability, physiological immaturity of the embryo, presence of inhibiting substances, dormant embryo, in addition to the combination of such factors. The same species may present more than one cause for its dormancy (Vivian et al., 2008; Pazuch et al., 2015).

Light and temperature may also induce dormancy or lead the seeds to overcome it, since they regulate the distribution of the germination throughout the year, as well as the variability of the species on the environment (Orzari et al., 2013). The temperature may directly or indirectly affect the germination, affecting the feasibility of the seeds, dormancy overcoming, deterioration, water absorption speed and biochemical reactions of the germination process (Marcos-Filho, 2015; Mahmood et al., 2016). Light may have a direct influence on the germination of the seeds, and it is associated to a dormancy mechanism, by controlling the substances that promote and inhibit germination, controlled by the phytochrome (Vivian et al., 2008; Lessa et al., 2013). When the seeds need light to germinate, they are characterized as positive photoblastic seeds, when their germination is reduced or inhibited in the presence of light, they are negative photoblastic seeds, and when their germination occurs regardless of the light, they are neutral photoblastic seeds (Marcos-Filho, 2015).

In addition to the factors that have already been mentioned, the seed deposition depth on the soil also affects the germination and emergence of the plants, through the availability of humidity, temperature and light exposition (Lee et al., 2011). The depth in which the seeds are able to germinate and emerge varies according to the species (Lee et al., 2011; Orzari et al., 2013; Luz et al., 2014). The germination of seeds and emergence of seedlings at higher or lower depths may determine which species will prevail on the different production systems.

Hence, studies related to the biology of weeds are important, since they may offer elements to develop adequate management techniques for invading species (Chauhan and Johnson, 2009; Orzari et al., 2013) and the reduction of the seed bank on the soil. Within this context, the objective of this study was to evaluate the effect of dormancy overcoming, light regimens, temperature variations and germination sowing depth of E. plantagineum seeds.

\section{Material and Methods}

The experiments were developed at the Didactic and Research Laboratory for Seeds from the Plant Science Department, Center for Rural Sciences, at the Federal University of Santa Maria, in the city of Santa Maria, RS, Brazil.

The E. plantagineum fruits were manually collected from a crop located in the municipality of Restinga Seca, RS, Brazil (29 $51^{\prime} 29^{\prime \prime} \mathrm{S}$ and $53^{\circ} 31^{\prime} 41^{\prime \prime} \mathrm{W}$ and $72 \mathrm{~m}$ of altitude), with a history of infestation by this weed $\left( \pm 20\right.$ plants. $\left.\mathrm{m}^{-2}\right)$. The collection area is characterized by soybean plantations (Glycine $\max (\mathrm{L}$.) Merrill) in the Summer and ryegrass plantations (Lolium multiflorum L.) during the Winter. The collection was made in November 2014, and only the fruits that showed dark coloration and that easily detached from the matrix plant were collected. They went through a manual cleaning process, and they were left to dry on the shade for five days and stored under an approximate humidity of $12 \%$, 
on flasks at room temperature $\left( \pm 25^{\circ} \mathrm{C}\right)$ until the experiments were conducted (eight months after the fruits were collected). For all experiments, the completely randomized experimental design was used (CRD), with four replications, and each replication was constituted by 50 diaspores (fruit agglutinated with the seed).

\section{Experiment I: Pre-germination treatments for dormancy overcoming}

After storing the diaspores, as previously described, the experiment was conducted after preliminary tests were conducted, on a Biochemical Oxygen Demand (B.O.D.) germination chamber, with a photoperiod of 24 hours and temperature of $25{ }^{\circ} \mathrm{C}$, in which it was observed that the seeds presented dormancy. The pilot tests and the dormancy overcoming studies were conducted on a transparent acrylic gerbox $(11.0 \times 11.0 \times 3.5 \mathrm{~cm})$, under three filter paper sheets moistened with distilled water at a quantity equivalent to 2.5 times the mass of the dry paper (Brasil, 2009). The substrate moisture was monitored daily, with the purpose of keeping it adequate for germination, and, when necessary, distilled water was added. The treatments used to overcome dormancy are described on Table 1.

On the treatments with potassium nitrate and gibberellic acid, after the end of the immersion time of the diaspores, they were cleansed with running water for $10 \mathrm{~min}$.

The variables analyzed were first germination count (07 days after sowing (DAS)), germination (14 DAS) and germination speed index (GSI) for 14 days, and the seed was considered germinated when the protrusion of the primary root occurred ( $\geq 2 \mathrm{~mm}$ ) according to Bewley and Black (1994). The germination percentage was calculated by the following equation: $\mathrm{G}(\%)=(\mathrm{N} / \mathrm{A}) \times 100$, where, $\mathrm{N}=$ number of germinated seeds, and $\mathrm{A}=$ total number of seeds available for germination, according to Labouriau and Valadares (1976). GSI was calculated by the equation GSI $=((\mathrm{G} 1 / \mathrm{N} 1)+(\mathrm{G} 2 / \mathrm{N} 2)+(\mathrm{Gn} / \mathrm{Nn}))$, where, $\mathrm{G}=$ number of germinated seeds in each count, and $\mathrm{N}=$ number of sowing days at every count (Maguire, 1962). The root and shoot length, as well as the dry mass of the seedlings were also evaluated at 14 DAS, according to Nakagawa (1999). At the end of the experiment, the feasibility of the seeds that did not germinate was evaluated through the tetrazolium test. For such, the diaspores were longitudinally sectioned in relation to the embryo, and they were stored on an aqueous solution of $2,3,5$ triphenyl tetrazolium chloride $(0.1 \%)$ at $35{ }^{\circ} \mathrm{C}$, for four hours, in the dark (Brasil, 2009). Then, they were cleansed in water, and the seeds were identified as dormant or dead according to the interpretation of the homogeneous pink coloration of the endosperm.

\section{Experiment II: temperatures and light regimens}

The experiment was conducted on a B.O.D. germination chamber, according to the methodology described on experiment I. It was arranged as a $7 \times 2$ factorial design (temperatures $\mathrm{x}$ light regimens). The first factor refers to the constant temperatures of $5,10,15,20,25,30$ and $35^{\circ} \mathrm{C}$, and the second factor to the presence or absence of light (photoperiod of 24 hours or continuous dark, respectively). On treatments with absence of light, the gerbox boxes were covered with two layers of aluminum paper, and the germination evaluations were conducted on a dark chamber under green light (Yamashita and Alberguini, 2011). For dormancy overcoming, the diaspores were immersed in potassium nitrate $(0.2 \%)$ for 12 hours, followed by immersion in the gibberellic acid solution (500 ppm) for 48 hours, and the after immersion period, they were cleansed in running water for 10 min (best treatment for experiment I).

The evaluations conducted on this experiment were germination at 7 and 14 DAS, root and shoot length, dry mass of seedlings and seed feasibility, according to the methodology described on experiment I.

Table 1. Pre-germination treatments used to overcome dormancy on E. Plantagineum seeds.

\begin{tabular}{clc}
\hline & \multicolumn{1}{c}{ Treatments } & $\begin{array}{c}\text { Exposure time } \\
\text { (h) }\end{array}$ \\
\hline T1 & Accelerated aging $\left(42^{\circ} \mathrm{C}\right)$ & 24 \\
T2 & Accelerated aging $\left(42^{\circ} \mathrm{C}\right)$ & 48 \\
T3 & Accelerated aging $\left(42^{\circ} \mathrm{C}\right)$ & 72 \\
T4 & Accelerated aging $\left(42^{\circ} \mathrm{C}\right)$ & 96 \\
T5 & Potassium nitrate immersion $(0.2 \%)$ & 6 \\
T6 & Potassium nitrate immersion $(0.2 \%)$ & 12 \\
T7 & Potassium nitrate immersion $(0.2 \%)$ & 18 \\
T8 & Potassium nitrate immersion $(0.2 \%)$ & 24 \\
T9 & Gibberellic acid immersion $(250 \mathrm{ppm})$ & 48 \\
T10 & Gibberellic acid immersion $(500 \mathrm{ppm})$ & 48 \\
T11 & Gibberellic acid immersion $(750 \mathrm{ppm})$ & 48 \\
T12 & Gibberellic acid immersion $(1000 \mathrm{ppm})$ & 48 \\
T13 & Gibberellic acid immersion $(1500 \mathrm{ppm})$ & 48 \\
& Potassium nitrate $(0.2 \%)+$ Gibberellic & $12+48$ \\
T14 & acid $(125 \mathrm{ppm})$ & $12+48$ \\
& Potassium nitrate $(0.2 \%)+$ Gibberellic & \\
T15 & acid $(250 \mathrm{ppm})$ & $12+48$ \\
T16 & Potassium nitrate $(0.2 \%)+$ Gibberellic & acid $(375 \mathrm{ppm})$ \\
& Potassium nitrate $(0.2 \%)+$ Gibberellic & $12+48$ \\
T17 & acid $(500 \mathrm{ppm})$ & \\
T18 & Potassium nitrate $(0.2 \%)+$ Gibberellic & $12+48$ \\
acid $(625 \mathrm{ppm})$ & Control & - \\
\hline
\end{tabular}




\section{Experiment III: sowing depth}

The experiment was conducted on a greenhouse, and each experimental unit was constituted by a plastic pot with capacity for 5 liters, filled with sifted sandy Dystrophic Red Acrisol (EMBRAPA, 2006). During the conduction of the experiment, in April 2016, the daily mean temperature was $21{ }^{\circ} \mathrm{C}$. The experiment was arranged as a $6 \times 2$ bifactorial design (sowing depth $\mathrm{x}$ soil coverage). The first factor refers to the sowing depths $(0,1,2,3,4$ and $5 \mathrm{~cm})$ and the second factor to whether or not the soil was covered with straw. The different sowing depths were obtained with the help of graduated scales. For soil coverage, ryegrass (Lolium multiflorum) straw was used, at a quantity equivalent to 3.0 t.ha $^{-1}$. The straw was collected in November 2015, when the ryegrass plants were under senescence, and they were left to dry on the shade for five days, cut and then stored on a dry location until the experiment was conducted. The pots were daily irrigated, and the necessary humidity was maintained in order to assure the germination of the seeds. In order to overcome the seed dormancy, the method described on experiment II was used. Each treatment was constituted by four pots, with 50 diaspores by pot.
Emergence evaluations were conducted at 7, 14 and 21 days after sowing (DAS), and the seedings that were considered as having emerged were the ones that showed a protrusion of the hypocotyl visible on the soil. In case of diaspores located on the soil surface, the emergence was considered when the seedlings began to open the cotyledons.

The data were submitted to analysis of variance through the $F$ test $(p<0.05)$ using the SISVAR program (Ferreira, 2011). The qualitative factors were compared using the Scott-Knott test at $5 \%$ of probability, and for the quantitative factors, the regression analysis was conducted $(\mathrm{p}<0.05)$. For percentage variables, the data were transformed using arcsine $\sqrt{ } \% / 100$, and the length of the shoot and root were transformed by $\sqrt{ } \mathrm{x}$.

\section{Results and Discussion}

\section{Pre-germination treatments for dormancy overcoming}

The most adequate treatment to overcome dormancy for $E$. plantagineum seeds was the immersion in $\mathrm{KNO}_{3}(0.2 \%)+\mathrm{AG}_{3}$ (500 ppm) (T17), with $86 \%$ of germination (Table 2). On the other hand, the treatments in which the seeds were submitted to

Table 2. Germination (G \%), first germination count (FGC \%), germination speed index (GSI) and viable dormant seeds (VD $\%)$ of E. plantagineum after the exposure of diaspores (fruits agglutinated with seeds) to pre-germination treatments to overcome the dormancy of the seeds.

\begin{tabular}{|c|c|c|c|c|c|c|}
\hline & Treatments & Time $(h)^{5}$ & $\mathrm{G}$ & $\mathrm{FGC}$ & GSI & VD \\
\hline $\mathrm{T} 1$ & $\mathrm{EA}^{2}$ & 24 & $21.5 \mathrm{f}^{1}$ & $18.0 \mathrm{f}$ & $3.0 \mathrm{e}$ & $55.0 \mathrm{~b}$ \\
\hline $\mathrm{T} 2$ & EA & 48 & $44.5 \mathrm{e}$ & $40.5 \mathrm{~d}$ & $6.8 \mathrm{c}$ & $39.0 \mathrm{c}$ \\
\hline $\mathrm{T} 3$ & EA & 72 & $28.5 \mathrm{f}$ & $22.5 \mathrm{f}$ & $3.7 \mathrm{e}$ & $49.7 \mathrm{~b}$ \\
\hline $\mathrm{T} 4$ & EA & 96 & $23.0 \mathrm{f}$ & $17.0 \mathrm{f}$ & $2.9 \mathrm{e}$ & $50.0 \mathrm{~b}$ \\
\hline T5 & $\mathrm{KNO}_{3}{ }^{3}$ & 6 & $23.5 \mathrm{f}$ & $21.5 \mathrm{f}$ & $3.4 \mathrm{e}$ & $53.5 \mathrm{~b}$ \\
\hline T6 & $\mathrm{KNO}_{3}$ & 12 & $26.0 \mathrm{f}$ & $25.5 \mathrm{f}$ & $5.7 \mathrm{~d}$ & $50.1 \mathrm{~b}$ \\
\hline $\mathrm{T} 7$ & $\mathrm{KNO}_{3}$ & 18 & $30.0 \mathrm{f}$ & $27.0 \mathrm{f}$ & $4.8 \mathrm{~d}$ & $54.0 \mathrm{~b}$ \\
\hline $\mathrm{T} 8$ & $\mathrm{KNO}_{3}$ & 24 & $24.5 \mathrm{f}$ & $24.5 \mathrm{f}$ & $5.0 \mathrm{~d}$ & $49.1 \mathrm{~b}$ \\
\hline Т9 & $\mathrm{AG}_{3}(250)^{4}$ & 48 & $56.5 \mathrm{~d}$ & $55.0 \mathrm{c}$ & $8.9 \mathrm{~b}$ & $29.5 \mathrm{~d}$ \\
\hline $\mathrm{T} 10$ & $\mathrm{AG}_{3}(500)$ & 48 & $53.5 \mathrm{~d}$ & $49.5 \mathrm{c}$ & $9.1 \mathrm{~b}$ & $34.9 \mathrm{~d}$ \\
\hline $\mathrm{T} 11$ & $\mathrm{AG}_{3}(750)$ & 48 & $50.5 \mathrm{~d}$ & $43.5 \mathrm{~d}$ & $6.7 \mathrm{c}$ & $40.8 \mathrm{c}$ \\
\hline $\mathrm{T} 12$ & $\mathrm{AG}_{3}(1000)$ & 48 & $42.5 \mathrm{e}$ & $38.0 \mathrm{e}$ & $5.8 \mathrm{~d}$ & $40.4 \mathrm{c}$ \\
\hline $\mathrm{T} 13$ & $\mathrm{AG}_{3}(1500)$ & 48 & $27.0 \mathrm{f}$ & $24.0 \mathrm{f}$ & $3.6 \mathrm{e}$ & $54.7 \mathrm{~b}$ \\
\hline $\mathrm{T} 14$ & $\mathrm{KNO}_{3}+\mathrm{AG}_{3}(125)$ & $12+48$ & $59.5 \mathrm{~d}$ & $50.0 \mathrm{c}$ & $9.4 \mathrm{~b}$ & $5.1 \mathrm{e}$ \\
\hline $\mathrm{T} 15$ & $\mathrm{KNO}_{3}+\mathrm{AG}_{3}(250)$ & $12+48$ & $71.0 \mathrm{c}$ & $44.0 \mathrm{~d}$ & $10.3 \mathrm{~b}$ & $5.0 \mathrm{e}$ \\
\hline $\mathrm{T} 16$ & $\mathrm{KNO}_{3}+\mathrm{AG}_{3}(375)$ & $12+48$ & $81.5 \mathrm{~b}$ & $62.5 \mathrm{~b}$ & $13.1 \mathrm{a}$ & $2.9 \mathrm{e}$ \\
\hline $\mathrm{T} 17$ & $\mathrm{KNO}_{3}+\mathrm{AG}_{3}(500)$ & $12+48$ & $86.0 \mathrm{a}$ & $78.5 \mathrm{a}$ & $14.9 \mathrm{a}$ & $1.9 \mathrm{e}$ \\
\hline $\mathrm{T} 18$ & $\mathrm{KNO}_{3}+\mathrm{AG}_{3}(625)$ & $12+48$ & $78.5 \mathrm{~b}$ & $73.5 \mathrm{a}$ & $12.5 \mathrm{a}$ & $3.0 \mathrm{e}$ \\
\hline $\mathrm{T} 19$ & Control & & $0.0 \mathrm{~g}$ & $0.0 \mathrm{~g}$ & $0.0 \mathrm{f}$ & $85.0 \mathrm{a}$ \\
\hline \multicolumn{3}{|c|}{$\mathrm{F}^{6}$ Value } & $89.88 *$ & $33.64^{*}$ & $43.10^{*}$ & $94.86^{*}$ \\
\hline \multicolumn{3}{|c|}{$\mathrm{CV}(\%)^{7}$} & 6.7 & 10.3 & 8.8 & 9.7 \\
\hline
\end{tabular}

*Significant at $5 \%$ of error probability, according to the $\mathrm{F}$ test. ${ }^{1}$ Means not followed by the same letter on the row differ from each other, according to the ScottKnott test, $\mathrm{p}<0.05 .{ }^{2}$ Accelerated aging $\left(42{ }^{\circ} \mathrm{C}\right) .{ }^{3}$ Potassium nitrate $(0.2 \%) .{ }^{4}$ Gibberellic acid $(\mathrm{ppm}) .{ }^{5}$ Immersion time of diaspores (fruits agglutinated with the seed) in the solutions. ${ }^{6}$ Transformed data. ${ }^{7}$ Coefficient variation percentage. 
accelerated aging (24, 72 and $96 \mathrm{~h})(\mathrm{T} 1, \mathrm{~T} 3$ and T4), immersion in $\mathrm{KNO}_{3}(0.2 \%)$ (T5 - T8) and $\mathrm{AG}_{3}(1500 \mathrm{ppm})$ (T13) showed reduced efficiency, since the germination was lower than the other studied treatments, varying from 21.5 to $30.0 \%$, which is statistically different than experiment T17, explained above. However, all treatments promoted an increase in germination in relation to the control (T19), with no dormancy overcoming method, for which there was no seed germination.

Among the most effective treatments to overcome dormancy are the ones in which the diaspores were immersed in $\mathrm{KNO}_{3}(0.2 \%)+\mathrm{AG}_{3}$ at 500 and $625 \mathrm{ppm}$ (T17 and $\left.\mathrm{T} 18\right)$, showing no statistical difference for the vigor variable (FGC at 7 DAS). For the seed germination variable (14 DAS), a significant difference occurred among the concentrations used, and $500 \mathrm{ppm}$ was the most efficient one for this characteristic (Table 2). When combining $\mathrm{KNO}_{3}$ and $\mathrm{AG}_{3}$, a synergic effect occurred on the dormancy overcoming of E. plantagineum seeds in comparison to the isolated effect of both agents, according to the evaluated characteristics. In addition, for these treatments, only a small percentage of the seeds left to germinate remained dormant, indicating that dormancy was efficiently overcome.
The results for the shoot length of E. plantagineum seedlings are in agreement with those observed for vigor and germination, for which the treatments that had $\mathrm{KNO}_{3}(0,2 \%)$ $+\mathrm{AG}_{3}(125,250,500$ and $625 \mathrm{ppm})$ and only $\mathrm{AG}_{3}(250 \mathrm{ppm})$ offered, in general, the greatest lengths, differing statistically from the other treatments (Table 3). For the root length of the seedlings, the most adequate treatments were accelerated aging (24 h), $\mathrm{KNO}_{3}(6$ and $18 \mathrm{~h}), \mathrm{AG}_{3}(250,750,1000$ and $1500 \mathrm{ppm})$ and $\mathrm{KNO}_{3}(0,2 \%)+\mathrm{AG}_{3}(500 \mathrm{ppm})$, for which the largest lengths were observed. As to the dry mass, the best treatments were accelerated aging $(48 \mathrm{~h}), \mathrm{KNO}_{3}(6 \mathrm{~h})$, $\mathrm{AG}_{3}(250,500$ and $1500 \mathrm{ppm})$ and $\mathrm{KNO}_{3}(0.2 \%)+\mathrm{AG}_{3}(125$, 250,375 and $500 \mathrm{ppm}$ ), differing statistically from the other treatments. In relation to the total length of the seedling, it was observed that the immersion of diaspores in $\mathrm{AG}_{3}(250$ ppm) showed the highest efficiency, with $6.9 \mathrm{~cm}$.

The efficiency of $\mathrm{AG}_{3}$ to overcome dormancy may be related to the hydrolysis control of the reserves, by inducing a new synthesis of $\alpha$-amylase, increasing the synthesis of proteins on the seeds, and offering cell lengthening, causing the primary root to break the tissues that restrict its growth (Yamaguchi, 2008; Vivian et al., 2008; Taiz and Zeiger, 2013). In addition,

Table 3. Shoot length (ST, cm), root length (RT, $\mathrm{cm})$, total length $(\mathrm{TL}, \mathrm{cm})$ and dry mass (DM, $\left.\mathrm{mg}^{\mathrm{p}} \mathrm{l}^{-1}\right)$, of seedlings obtained from the germination of E. plantagineum seeds after pre-germination treatments to overcome dormancy.

\begin{tabular}{|c|c|c|c|c|c|c|}
\hline & Treatments & Time $(\mathrm{h})^{5}$ & $\mathrm{ST}^{6}$ & $\mathrm{RT}^{6}$ & $\mathrm{TL}^{7}$ & $\mathrm{DM}^{7}$ \\
\hline $\mathrm{T} 1$ & $\mathrm{EA}^{2}$ & 24 & $2.0 \mathrm{~b}^{1}$ & $3.4 \mathrm{a}$ & $5.4 \mathrm{c}$ & $2.2 \mathrm{~b}$ \\
\hline $\mathrm{T} 2$ & EA & 48 & $1.1 \mathrm{~d}$ & $2.5 \mathrm{~b}$ & $3.6 \mathrm{~d}$ & $2.6 \mathrm{a}$ \\
\hline $\mathrm{T} 3$ & EA & 72 & $1.3 \mathrm{~d}$ & $1.4 \mathrm{c}$ & $2.7 \mathrm{e}$ & $1.8 \mathrm{c}$ \\
\hline $\mathrm{T} 4$ & EA & 96 & $1.3 \mathrm{~d}$ & $1.6 \mathrm{c}$ & $2.9 \mathrm{e}$ & $1.9 \mathrm{c}$ \\
\hline $\mathrm{T} 5$ & $\mathrm{KNO}_{3}{ }^{3}$ & 6 & $1.2 \mathrm{~d}$ & $3.6 \mathrm{a}$ & $4.8 \mathrm{c}$ & $2.7 \mathrm{a}$ \\
\hline T6 & $\mathrm{KNO}_{3}$ & 12 & $1.6 \mathrm{c}$ & $2.2 \mathrm{~b}$ & $3.8 \mathrm{~d}$ & $2.3 \mathrm{~b}$ \\
\hline $\mathrm{T} 7$ & $\mathrm{KNO}_{3}$ & 18 & $1.2 \mathrm{~d}$ & $4.0 \mathrm{a}$ & $5.2 \mathrm{c}$ & $2.3 \mathrm{~b}$ \\
\hline $\mathrm{T} 8$ & $\mathrm{KNO}_{3}$ & 24 & $1.3 \mathrm{~d}$ & $2.1 \mathrm{~b}$ & $3.4 \mathrm{e}$ & $2.0 \mathrm{c}$ \\
\hline T9 & $\mathrm{AG}_{3}(250)^{4}$ & 48 & $2.6 \mathrm{a}$ & $4.4 \mathrm{a}$ & $6.9 \mathrm{a}$ & $2.9 \mathrm{a}$ \\
\hline $\mathrm{T} 10$ & $\mathrm{AG}_{3}(500)$ & 48 & $2.3 \mathrm{~b}$ & $2.0 \mathrm{~b}$ & $4.3 \mathrm{~d}$ & $2.6 \mathrm{a}$ \\
\hline $\mathrm{T} 11$ & $\mathrm{AG}_{3}(750)$ & 48 & $2.4 \mathrm{~b}$ & $3.5 \mathrm{a}$ & $5.9 \mathrm{~b}$ & $2.4 \mathrm{~b}$ \\
\hline $\mathrm{T} 12$ & $\mathrm{AG}_{3}(1000)$ & 48 & $2.2 \mathrm{~b}$ & $3.3 \mathrm{a}$ & $5.5 \mathrm{c}$ & $2.4 \mathrm{~b}$ \\
\hline T13 & $\mathrm{AG}_{3}(1500)$ & 48 & $2.2 \mathrm{~b}$ & $3.1 \mathrm{a}$ & $5.3 \mathrm{c}$ & $2.7 \mathrm{a}$ \\
\hline T14 & $\mathrm{KNO}_{3}+\mathrm{AG}_{3}(125)$ & $12+48$ & $2.8 \mathrm{a}$ & $1.9 \mathrm{~b}$ & $4.7 \mathrm{c}$ & $2.9 \mathrm{a}$ \\
\hline $\mathrm{T} 15$ & $\mathrm{KNO}_{3}+\mathrm{AG}_{3}(250)$ & $12+48$ & $2.9 \mathrm{a}$ & $2.2 \mathrm{~b}$ & $5.1 \mathrm{c}$ & $3.3 \mathrm{a}$ \\
\hline T16 & $\mathrm{KNO}_{3}+\mathrm{AG}_{3}(375)$ & $12+48$ & $2.0 \mathrm{~b}$ & $2.5 \mathrm{~b}$ & $4.5 \mathrm{c}$ & $2.8 \mathrm{a}$ \\
\hline $\mathrm{T} 17$ & $\mathrm{KNO}_{3}+\mathrm{AG}_{3}(500)$ & $12+48$ & $2.8 \mathrm{a}$ & $3.3 \mathrm{a}$ & $6.1 \mathrm{~b}$ & $2.7 \mathrm{a}$ \\
\hline $\mathrm{T} 18$ & $\mathrm{KNO}_{3}+\mathrm{AG}_{3}(625)$ & $12+48$ & $2.8 \mathrm{a}$ & $2.6 \mathrm{~b}$ & $5.3 \mathrm{c}$ & $2.4 \mathrm{~b}$ \\
\hline T19 & Control & & $0.0 \mathrm{e}$ & $0.0 \mathrm{~d}$ & $0.0 \mathrm{f}$ & $0.0 \mathrm{~d}$ \\
\hline \multicolumn{3}{|c|}{ F Value } & $28.34 *$ & $9.88 *$ & $11.44^{*}$ & $5.52 *$ \\
\hline \multicolumn{3}{|c|}{$\mathrm{CV}(\%)^{8}$} & 6.3 & 10.1 & 14.1 & 13.3 \\
\hline
\end{tabular}

*Significant at $5 \%$ of error probability, though the $\mathrm{F}$ test. ${ }^{1}$ Means not followed by the same letter on the column differ from each other, according to the ScottKnott test, $\mathrm{p}<0.05 .{ }^{2}$ Accelerated aging. ${ }^{3}$ Potassium nitrate $(0.2 \%) .{ }^{4}$ Gibberellic acid (ppm). ${ }^{5}$ Time of immersion of the diaspores (fruits agglutinated with the seed) on the solutions. ${ }^{6}$ Transformed data. ${ }^{7}$ Data with no transformation. ${ }^{8}$ Coefficient variation percentage. 
gibberellins may affect the metabolism of glycines and cause the increase of the cell wall plasticity, controlling the action of enzymes that may regulate the water flow on the cells during expansion (Yamaguchi, 2008; Taiz and Zeiger, 2013). According to Taiz and Zeiger (2013), this phytormonium also stimulates embryo maturity. $\mathrm{KNO}_{3}$ is involved in dormancy overcoming by acting as an electron receptor, reoxidizing NADPH and increasing the availability of NADP in order to reduce the pentose-phosphate cycle due to hydrogenases (Copeland and McDonald, 1995). However, $\mathrm{KNO}_{3}$ does not act in isolation, and it may have a synergic effect with $\mathrm{AG}_{3}$ (Marcos-Filho, 2015), which may explain the increase in germination on treatments with $\mathrm{KNO}_{3}+\mathrm{AG}_{3}$.

\section{Temperatures and light regimens}

The E. plantagineum seeds germinated both in the presence and the absence of light, according to the first count (7 DAS) and germination (14 DAS), but they were preferably favored by the presence of light (Table 4), showing that this species may be classified as preferentially positively photoblastic (Klein and Felippe, 1991). On the first germination count, the ideal temperature was 19.3 and $19.1{ }^{\circ} \mathrm{C}$, with maximum germination of 94.6 and $84.4 \%$, in the presence and absence of light, respectively (Figure 1A). At 14 DAS (Figure 1B), it was observed that, regardless of the presence or absence of light, at a temperature of $18.7^{\circ} \mathrm{C}$, the estimated seed germination was $100 \%$, and this temperature was considered ideal. Although the maximal germination occurs at temperatures close to $20{ }^{\circ} \mathrm{C}$, germination also occurred at temperatures of 5 and $35^{\circ} \mathrm{C}$, with percentages close to $5 \%$. This shows the capacity of this species to adapt to a wide range of temperatures, probably characterized as an escalation process to occupy the land, according to the temperature changes that occur during the seasons of the year. In relation to the tetrazolium test (Figure 2), which evaluates the

Table 4. Germination (G \%), first germination count (FGC \%), viable dormant seeds (VD \%), shoot length ST (cm), root length RT $(\mathrm{cm})$, total length TL $(\mathrm{cm})$ and dry mass DM $\left(\mathrm{mg}_{\mathrm{pl}} \mathrm{pl}^{-1}\right)$ of seedlings obtained from E. plantagineum seeds submitted to different temperatures and light regimens.

\begin{tabular}{|c|c|c|c|c|c|c|c|}
\hline & $\mathrm{G}$ & FGC & VD & ST & RT & $\mathrm{TL}^{3}$ & $\mathrm{DM}^{3}$ \\
\hline Light & $61 \mathrm{~A}^{1}$ & $54 \mathrm{~A}$ & $33^{\mathrm{ns}}$ & $1.5 \mathrm{~A}$ & $2.4 \mathrm{~A}$ & $3.9 \mathrm{~A}$ & $1.9^{\mathrm{ns}}$ \\
\hline Dark & $57 \mathrm{~B}$ & $47 \mathrm{~B}$ & 32 & $2.0 \mathrm{~B}$ & $1.7 \mathrm{~B}$ & $3.6 \mathrm{~B}$ & 2.0 \\
\hline & \multicolumn{7}{|c|}{ Valor de $\mathrm{F}^{2}$} \\
\hline Temperature (A) & $482.27 *$ & $257.48^{*}$ & $257.41 *$ & $125.14 *$ & $92.00 *$ & $139.39 *$ & $27.65^{*}$ \\
\hline Light (D) & $14.60 *$ & $17.26^{*}$ & $0.03^{\mathrm{ns}}$ & $10.81 *$ & $55.80 *$ & $4.98^{*}$ & $0.17^{\mathrm{ns}}$ \\
\hline $\mathrm{A}^{*} \mathrm{D}$ & $3.98 *$ & $3.50 *$ & $3.29 *$ & $15.29 *$ & $5.02 *$ & $3.87 *$ & $3.51^{*}$ \\
\hline $\mathrm{CV}(\%)^{4}$ & 7.5 & 10.8 & 13.2 & 10.3 & 8.7 & 14.1 & 13.2 \\
\hline
\end{tabular}

*Significant at $5 \%$ of error probability, trough the $\mathrm{F}$ test. ${ }^{1}$ Means not followed by the same letter on the column differ from each other, according to the ScottKnott test, $\mathrm{p}<0.05 .{ }^{2}$ Transformed data. ${ }^{3}$ Data with no transformation. ${ }^{4}$ Coefficient variation percentage.

A

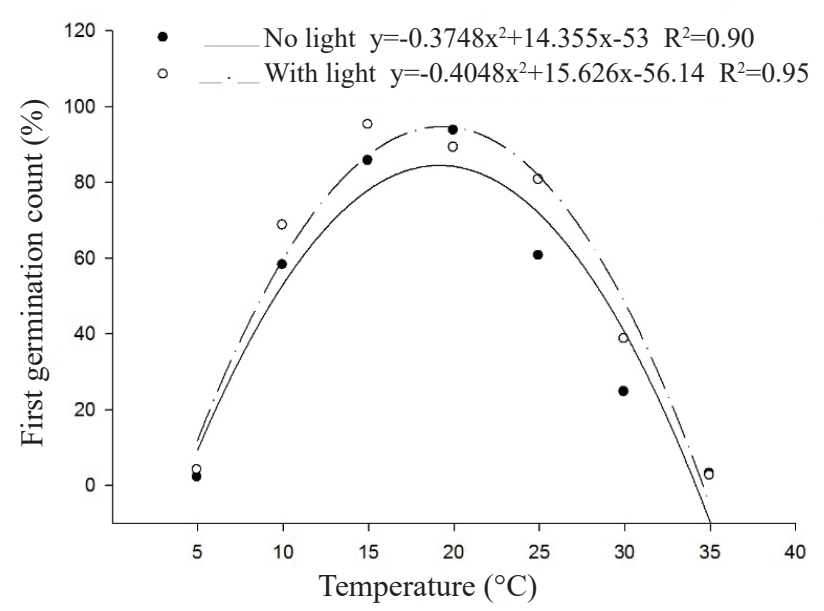

B

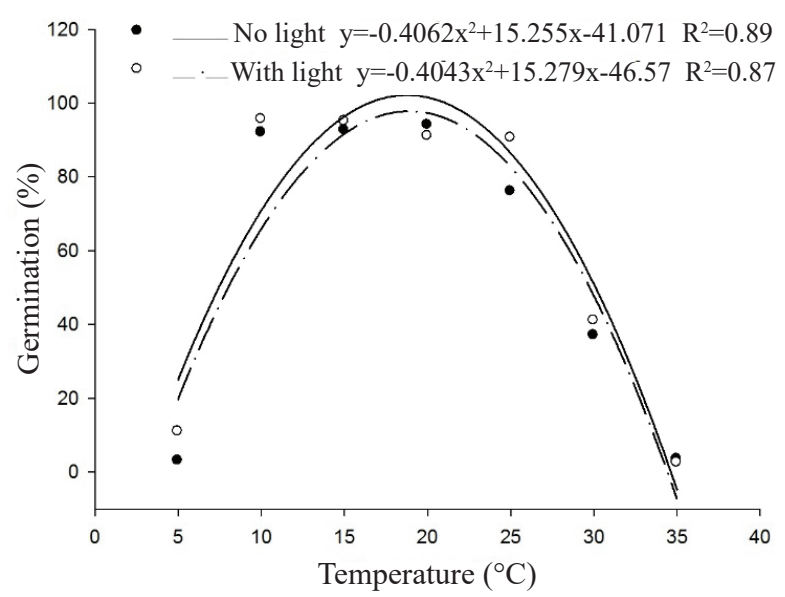

Figure 1. First germination count (A) and germination percentage at 14 days after sowing (B) of the E. plantagineum diaspores (fruit agglutinated with the seed), submitted to different temperatures and light regimens. 


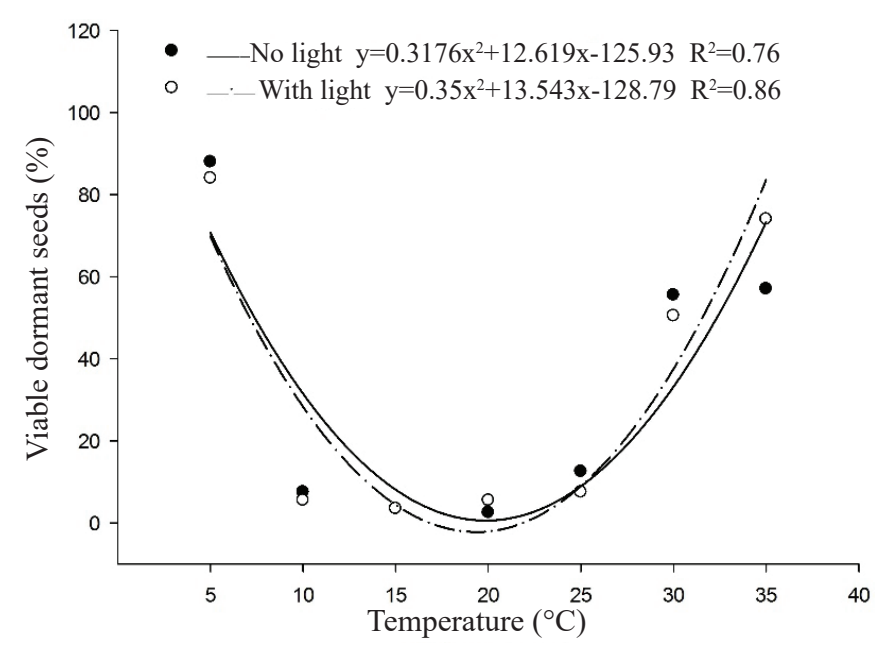

Figure 2. Viability of the E. plantagineum seeds submitted to different temperatures and light regimens.

feasibility of the seeds, it was observed that non-germinated seeds, at extreme temperatures, were viable, indicating that these temperatures inhibit the germination process, since they are kept dormant.

The results of this experiment confirm those found by Piggin (1976), who, by evaluating the influence of light and temperature in the germination of E. plantagineum seeds collected in the Southeast region of Australia, observed that the temperature range of 15 to $25^{\circ} \mathrm{C}$ offered maximum germination of the seeds, regardless of the presence or absence of light; however, germination was also obtained at $40{ }^{\circ} \mathrm{C}$.

For the shoot and root length, total length and dry mass of the E. plantagineum seedlings (Figure 3), it may be observed that, in general, an increase trend occurred for these characteristics from 5 to $20^{\circ} \mathrm{C}$, decreasing at higher temperatures, from 20 to $35^{\circ} \mathrm{C}$. At temperatures close to $20^{\circ} \mathrm{C}$, the greatest shoot, root and total length and dry mass were observed for the seedlings, both in the presence and the absence of light. This indicates that, at the temperature range from 15 to $25{ }^{\circ} \mathrm{C}$, in addition to the maximum germination, normal seedlings were formed, with larger growth of the primary structures. In opposition, at
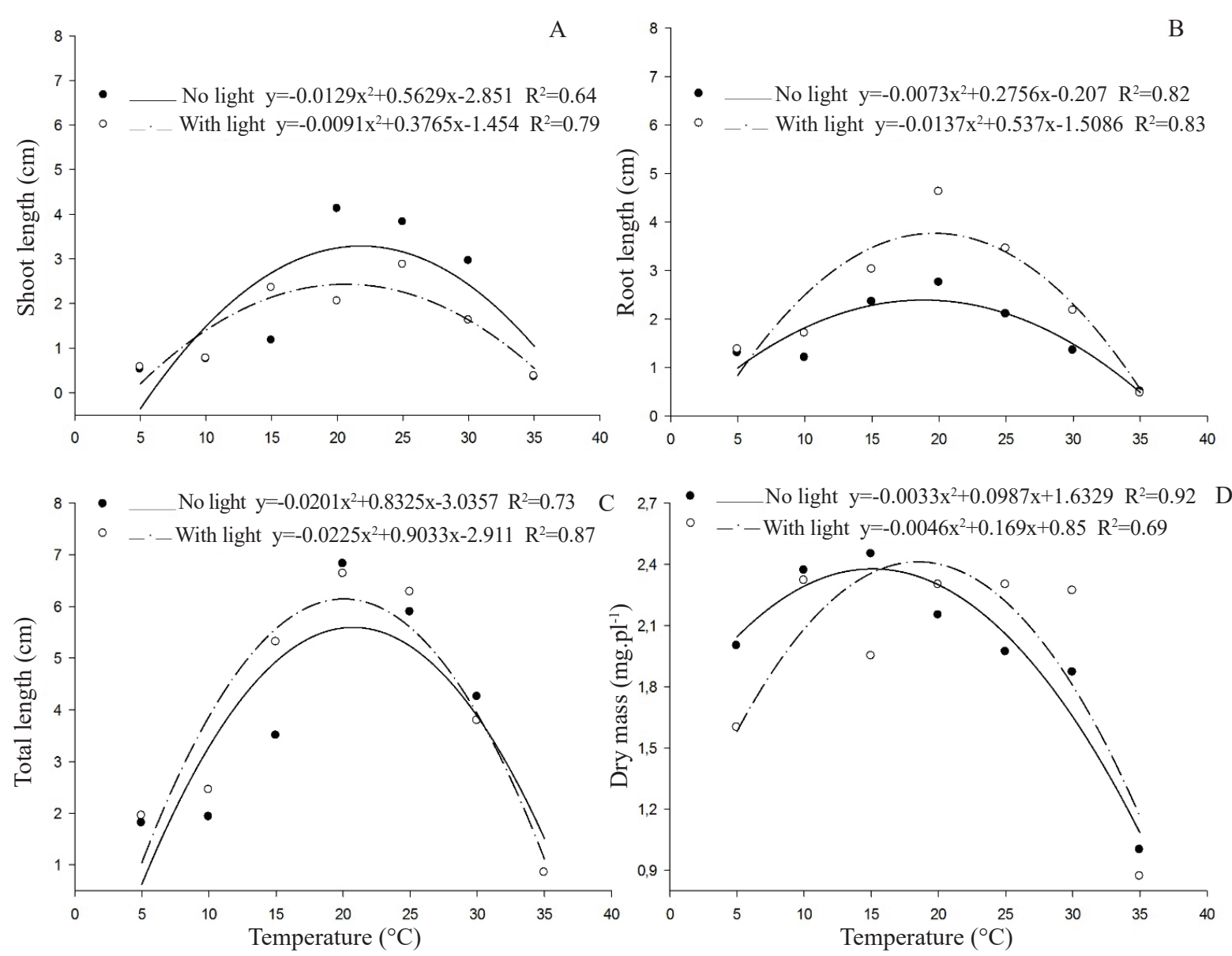

Figure 3. Shoot length (A), root length (B), total length (C) and dry mass (D) of E. plantagineum seedlings obtained from seeds submitted to different temperatures and light regimens. 
extreme temperatures, close to 5 and $35^{\circ} \mathrm{C}$, low germination occurred, as well as reduced growth of primary structures, regardless of the light regimen.

Temperature and light demand work as sensors for the seed positioning on the soil and for the shading conditions in relation to neighboring adult plants, in which the seeds of positive photoblastic species, located at greater depths do not germinate (Vidal et al., 2007). On the other hand, for seeds on the soil coverage, with the presence of vegetable coverage, the latter filters light, which does not stimulate germination. However, for E. plantagineum, even as a preferably positively photoblastic species, it also germinates in the absence of light; in that sense, the use of cultural control methods through soil coverage plants or vegetable residues (straw), aiming to reduce the access of the seed to light, may not be efficient management methods.

\section{Sowing depth}

As the sowing depth increased $(0.0$ to $5.0 \mathrm{~cm})$, a strong decrease of the seedling emergence occurred (Figure 4A), and the highest percentages were observed when the seeds were positioned on the soil surface $(0.0 \mathrm{~cm})$, whose mean values varied between 48 and $72 \%$ for 7 and 21 DAS, respectively. This may have occurred because they are more exposed to daily temperature fluctuations, when located on the soil surface, contributing to increase emergence (Canossa et al., 2007). On the other hand, the decrease on the emergence as the sowing depth increased may be related to the fact that greater depths represent a physical barrier imposed by the soil, and since these are small seeds, their reserves are insufficient for them to emerge at greater depths (Canossa et al., 2007; Lee et al., 2011; Luz et al., 2014), creating a seed bank on the soil (Lessa et al., 2013).

The treatments in which straw was used as vegetable coverage showed greater emergence percentage for $E$. plantagineum seedlings at 7, 14 and 21 DAS, differing statistically from the treatments with exposed soil, without vegetable coverage (Figure 4B). This may have occurred because the straw keeps the soil coverage humid, preventing drying and offering a more adequate environment for germination, favoring the seeds on the soil surface. In addition, these results corroborate with those obtained on the previous experiment, for which, even with greater germination in the presence of light, the seeds also germinated efficiently in the absence of light. This confirms that the seeds of this species are able to germinate even in the presence of vegetable coverage with straw at a quantity equivalent to $3 \mathrm{t}^{-h^{-1}}$. Considering that, the management using straw as vegetable coverage may not be an efficient alternative to suppress germination and the emergence of E. plantagineum, in the areas where it is considered an invasive plant.

\section{Conclusions}

Echium plantagineum seeds showed intrinsic dormancy, which is overcome with the use of the pre-germination treatment with $\mathrm{KNO}_{3}(0.2 \%)+\mathrm{AG}_{3}(500$ ppm).

E. plantagineum seeds are preferably positively
A

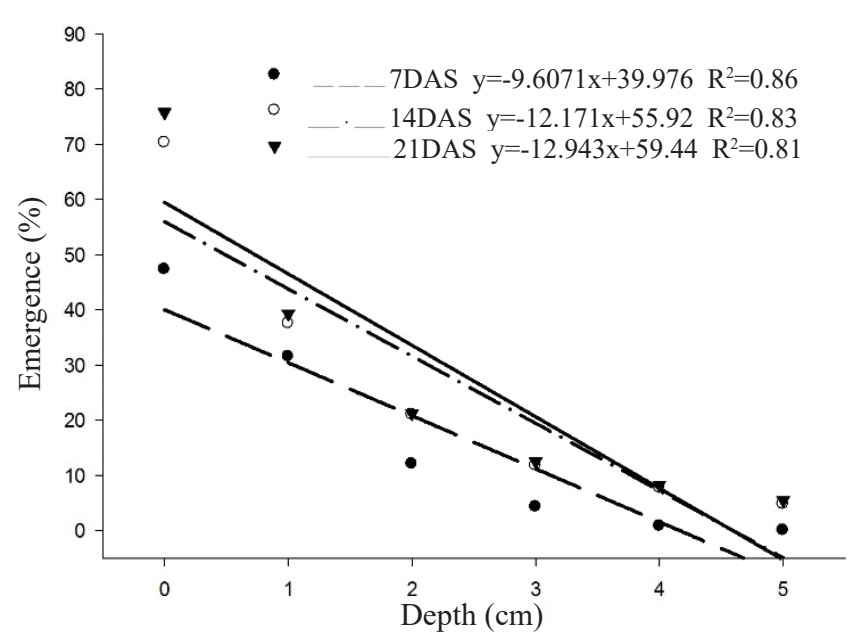

B

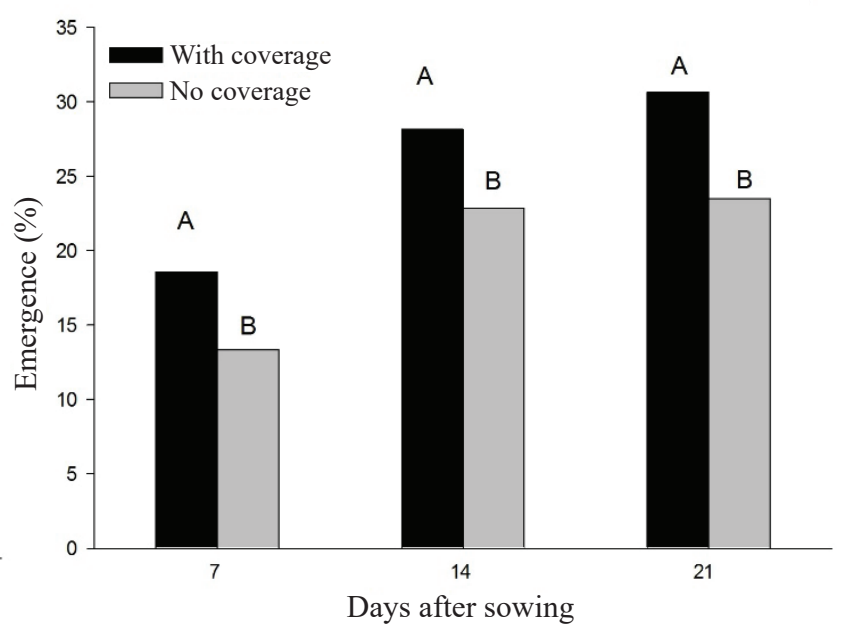

Figure 4. Emergence of the seedlings at 7, 14 and 21 days after sowing (DAS), obtained from E. plantagineum diaspores (fruit agglutinated with the seed) submitted to different sowing depths (A) and vegetable coverage (B). Different uppercase letters on the bars, in each evaluation date, are different from each other, according to the Scott-Knott test, $\mathrm{p}<0.05$. Coefficient variation (\%): 27, 21 and 22 for 7, 14 and 21 DAS, respectively. 
photoblastic and their germination occurs more efficiently at a temperature of $20^{\circ} \mathrm{C}$.

The greatest emergence of $E$. plantagineum seedlings occurs when the seeds are allocated on the soil surface, with ryegrass straw coverage.

\section{References}

AZANIA, C.A.M.; MARQUES, R.P.; AZANIA, A.A.P. M.; ROLIM, J.C. Superação da dormência de sementes de corda-deviola (Ipomoea quamoclit e I. hederifolia). Planta Daninha, v.27, n. 1, p.23-27, 2009. http://www.scielo.br/scielo.php?script=sci_ arttext\&pid=S0100-83582009000100004

BERTI, M.; JOHNSON, B.L.; DASH, S.; FISCHER, S.; WILCKENS, R.; HEVIA, F. Echium: a source of stearidonic acid adapted to the northern great plains in the US. Issues in new crops and new uses. Alexandria: ASHS Press, 2007.125p. https://hort. purdue.edu/newcrop/ncnu07/pdfs/berti120-125.pdf

BEWLEY, J. D.; BLACK, M. Seeds: physiology of development and germination. New York: Plenum Press, 2ed. 1994. 445p.

BRASIL. Ministério da Agricultura, Pecuária e Abastecimento. Regras para análise de sementes. Ministério da Agricultura, Pecuária e Abastecimento. Secretaria de Defesa Agropecuária. Brasília: MAPA/ACS, 2009. 395p. http://www.agricultura.gov.br/arq_editor/ file/2946_regras_analise_sementes.pdf

CANOSSA, R.S.; OLIVEIRA, JR.R.S.; CONSTANTIN, J.; BIFFE, D.F.; ALONSO, D.G.; FRANCHINI, L. H. H. Profundidade de semeadura afetando a emergência de plântulas de Alternanthera tenella.PlantaDaninha, v.25,n.4,p.719-725,2007.http://www.scielo. br/scielo.php?script=sci_arttext\&pid=S0100-83582007000400008

CHAUHAN, B.S.; JOHNSON, D.E. Seed germination ecology of junglerice (Echinochloa colona): a major weed of rice. Weed Science, v.57, n.3, p.235-240, 2009. http://www.bioone.org/doi/abs/10.1614/ WS-08-141.1?journalCode=wees

COMUNIAN, T.A.; BOILLON, M.R.G.; THOMAZINI, M.; NEGUEIRA, M.S.; CASTRO, I.A.; FAVARO-TRINDADE, C.S. Protection of Echium oil by microencapsulation with phenolic compounds. Food Research International, v.88, p.144121, 2016. http://www.sciencedirect.com/science/article/pii/ S0963996916300849

COPELAND, L.O.; MCDONALD, M.B. Principles of seed science and technology. New York: Chapman \& Hall, 1995. 409p.

DUDDU, H.S.N.; SHIRTLIFFE, S.J. Variation of seed dormancy and germination ecology of cowcockle (Vaccaria hispanica). Weed Science, v.62, n.3, p.483-492, 2014. http://www.bioone.org/doi/ abs/10.1614/WS-D-13-00125.1

EMBRAPA. Empresa Brasileira de Pesquisa Agropecuária. Sistema brasileiro de classificação de solos. 2 ed., Rio de Janeiro: Embrapa Solos, 2006. 306p.
FERREIRA, D. F. Sisvar: a computer statistical analysis system. Ciência e Agrotecnologia, v.35, n.6, p.1039-1042, 2011. http://www. scielo.br/scielo.php?pid=S1413-70542011000600001\&script=sci arttext

FORCELLA, F.; WOOD, J.T.; DILLON, S.P. Characteristic's distinguishing invasive weeds within Echium (Bugloss). Weed Research, v.26, p.351-364, 1986. http://onlinelibrary.wiley.com/ doi/10.1111/j.1365-3180.1986.tb00718.x/abstract

GAMA, J. S. M.; ALVES, E.U.; BRUNO, R.L.A.; PEREIRA JUNIOR, L.R.; BRAGAJUNIOR, J. M.; MONTE, D.M.O. Superação de dormência em sementes de Centrosema plumieri Benth. Revista Brasileira de Sementes, v.33, n.4, p.643-651, 2011. http://www.scielo. br/scielo.php?script $=$ sci_arttext\&pid=S0101-31222011000400006

KLEIN, A.; FELIPPE, G.M. Efeito da luz na germinação de sementes de ervas invasoras. Pesquisa Agropecuária Brasileira, v. 26, n. 7, p. 955-966, 1991.

LABOURIAU, L.G.; VALADARES, M.E.B. On the germination of seeds of Calotropis procera (Ait.) Ait.f. Anais da Academia Brasileira de Ciências, v. 48, n. 2, p. 263-284, 1976.

LEE, J.; CHAUHAN, B. S.; JOHNSON, D. E. Germination of fresh horse purslane (Trianthema portulacastrum) seeds in response to different environmental factors. Weed Science, v.59, n.4, p.495-499, 2011. http://www.bioone.org/doi/abs/10.1614/WS-D-11-00002.1

LESSA, B.F.T.; FERREIRA, V.M.; NETO, J.C.A.; SOUZA, R.C. Germinação de sementes de Emilia coccinea (Sims) G. DON em função da luminosidade, temperatura, armazenamento e profundidade de semeadura. Semina: Ciências Agrárias, v.34, n.6, p.3193-3204, 2013. http://www.uel.br/revistas/uel/index.php/semagrarias/article/ view/11968

LUZ, F.N.; YAMASHITA, O.M.; FERRARESI, D.A.; CARVALHO, M.A.C.; CAMPOS, O.R.; KOGA, P.S.; MASSAROTO, J.A. Interferência de luz, temperatura, profundidade de semeadura e palhada na germinação e emergência de Murdannia nudiflora. Comunicata Scientiae, v. 5, n. 1, p.25-33, 2014. https:// comunicatascientiae.com.br/comunicata/article/view/238

MAGUIRE, J. D. Speed of germination-aid in selection and evaluation for seedling emergence and vigor. Crop Science, v.2, n.2, p.176-177, 1962. https://dl.sciencesocieties.org/publications/cs/ abstracts/2/2/CS0020020176

MAHMOOD, A.H.; FLORENTINE, S.K.; CHAUHAN, B.S.; McLAREN, D.A.; PALMER, G.C.; WRIGHT, W. Influence of various environmental factors on seed germination and seedling emergence of a noxious environmental weed: green galenia (Galenia pubescens). Weed Science, v.64, n. 3, p. 486-494, 2016. http://www. bioone.org/doi/10.1614/WS-D-15-00184.1

MARCOS-FILHO, J. Fisiologia de sementes de plantas cultivadas. Londrina: ABRATES, 2015. 660 p.

MOREIRA, H.J.C.; BRAGANÇA, H.A.B.N. Manual de identificação de plantas infestantes - Cultivos de verão, 2010.650p. https://www.fmcagricola.com.br/portal/manuais/infestantes_verao/ index.html\#/1/ 
NAKAGAWA, J. Testes de vigor baseados na avaliação das plântulas. In: KRZYZANOWSKI, F. C.; VIEIRA, R.D.; FRANÇA-NETO, J.B. Vigor de sementes: conceitos e testes. Londrina: ABRATES. 1999.

ORZARI, I.; MONQUERO, P.A.; REIS, F.C.; SABBAG, R.S.; HIRATA, A.C.S. Germinação de espécies da família Convolvulaceae sob diferentes condições de luz, temperatura e profundidade de semeadura. Planta Daninha, v. 31, n. 1, p.53-61, 2013. http://www. scielo.br/pdf/pd/v31n1/06.pdf

PAZUCH, D.; TREZZI, M.M.; DIESEL, F.; BARANCELLI, M.V.J.; BATISTEL, S.C.; PASINI, R. Superação da dormência em sementes de três espécies de Ipomoea. Ciência Rural, v.45, n.2, p.192-199, 2015. http://revistas.bvs-vet.org.br/crural/article/view/24709

PIGGIN, C.M. Factors affecting seed germination of Echium plantagineum L. and Trifolium subterraneum L. Weed Research, v.16, p.337-344, 1976. http://onlinelibrary.wiley.com/ doi/10.1111/j.1365-3180.1976.tb00423.x/abstract

SHARMA, G.P.; ESLER, K.J. Phenotypic plasticity among Echium plantagineum populations in different habitats of western cape, South Africa. South African Journal of Botany, v.74, p.746749, 2008. http://www.sciencedirect.com/science/article/pii/ S0254629908002330

SOUZA, V.C.; LORENZI, H. Botânica sistemática: guia ilustrado para identificação das famílias de fanerógamas nativas e exóticas do Brasil, baseado em APG II. Nova Odessa: Instituto Plantarum, 2012.704p.
TAIZ, L.; ZEIGER, E. Fisiologia vegetal. Porto Alegre: Artmed, 2013. 954p.

VIDAL, R.A.; KALSING, A.; GOULART, I.C.G.R.; LAMEGO, F.P.; CHRISTOFFOLETO, P.J. Impacto da temperatura, irradiância e profundidade das sementes na emergência e germinação de Conyza bonariensis e Conyza canadenses resistentes ao glyphosate. Planta Daninha, v.25, n.2, p.309-315, 2007. http://www.scielo.br/scielo. php?script=sci_arttext\&pid=S0100-3582007000200010

VIVIAN, R.; SILVA, A.A.; GIMENES, JR.M.; FAGAN, E.B.; RUIZ, S.T.; LABONIA, V. Dormência em sementes de plantas daninhas como mecanismo de sobrevivência - breve revisão. Planta Daninha, v. 26, n. 3, p. 695-706, 2008. http://www.scielo.br/scielo. php?pid=S0100-83582008000300026\&script $=$ sci_abstract\&tlng $=$ pt

WESTON, L.A.; WESTON, P.A.; McCULLY, M. Production of bioactive napthoquinones by roots of paterson's curse (Echium plantagineum) implications for invasion success? Weed Science Research, v. 18, p. 677686, 2012. http://www.cabi.org/isc/FullTextPDF/2013/20133420034.pdf

YAMAGUCHI, S. Gibberellin metabolism and its regulation. Annual Review of Plant Biology, v.59, p.225-251, 2008. http://www. annualreviews.org/doi/abs/10.1146/annurev.arplant.59.032607.092804

YAMASHITA, O.M.; ALBERGUINI, A.L. Germinação de Vernonia ferruginea em função da quebra de dormência, luminosidade e temperatura. Comunicata Scientiae, v.2, n.3, p.142-148, 2011. https:// www.comunicatascientiae.com.br/comunicata/article/view/40v 